\title{
SLENDER EVIDENCE, WEIGHTY CONSEQUENCES: ON ONE WORD IN THE PERIPLUS MARIS ERYTHRAEI
}

\author{
Jan Vansina \\ University of Wisconsin-Madison
}

From time to time one encounters a situation where a wisp of a source yields evidence of momentous consequence for the understanding of a whole society in the past. Such a situation raises the question of how much evidentiary weight a slender source can credibly bear, for when the evidence is so slender or tenuous, the slightest misunderstanding or misinterpretation can lead to hugely magnified errors in historical reconstruction. At the same time, the more slender the evidence, the more tempted researchers will be to interpret it according to their own a priori vision of the past in question. This is a genuine problem which can only be overcome by finding more relevant evidence.

Such situations naturally crop up wherever sources (written or otherwise) are very rare, so that every scrap of evidence must be scrutinized and exploited with the greatest care and to its fullest extent, a common circumstance in African history in relation to written documents before ca. A.D. 1450 and documents at all times about topics such as, for instance, women's history or specific techniques of agriculture that were normally not recorded. The situation then, while unusual, is frequent enough to warrant a more detailed discussion of one such instance to illustrate what the problem is and how it can be tackled. This illustration will be the case of oratoi, a single word in the Periplus Maris Erythraei.

\section{II}

The Periplus is justly famous in African historiography. ${ }^{1}$ Known from a single manuscript now in Heidelberg and held to date from the early tenth century and a much later copy from that now in the British Museum, written in a mixture of classical and vulgar Greek by either a Greek living in Egypt or an Egyptian, and firmly dated to between AD 40-55, the Periplus contains the first, albeit succinct, information about the inhabitants of the East African coast, more than half a millennium before other comparable written mentions occur. ${ }^{2}$ In the circumstances it is no surprise that virtually its every word has been submitted to philological scrutiny, and none more so than the passage from paragraph 16 which describes the situation at Rhapta. This is the passage which includes the sentence: "Very big-bodied men [oratoi] inhabit the whole region and they behave each in his own place, just like chiefs." 3 To

History in Africa 24 (1997), 393-397. 
complicate matters, oratoi is a hapax lougomenon, that is, a word that does not occur as such anywhere else in ancient Greek writing.

Because the word oratoi is unique, the successive editors, translators, and commentators of this text have believed that the spelling must be corrupt, needing to be emendated to yield some other word. The earliest modern commentator Müller (1855) changed it to peiratai or "pirates," a reading which was accepted until very recently, and which still occurs in Huntingford's recently published translation. ${ }^{4}$ Müller may have been influenced by a passage in the Periplus (53:26) about the coast of India, which states that "there are pirates in these places." $\mathrm{Be}$ that as it may, it is fruitless now to speculate as to what exactly moved him to propose this particular emendation. But it certainly strains belief to accept that a scribe would have been so careless as to misread three letters pei-for a single $o$ - and then, for emphasis as it were, the second $-o-$ as an $-a-$. In this sense this emendation is a monstrosity and one cannot understand why Huntingford, who concedes that the emendation is "palaeographically violent," still clings to it.

In 1975 Giangrande established that, while the word oratoi might be unique, a word with the same stem preceded by an $a$-privative is common, especially in the medical literature, and means "blind." Therefore oratoi means

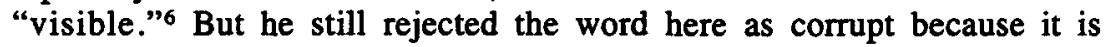
"contextually meaningless." $\mathrm{He}$ thinks that the alpha $(a)$ in this word was systematically misread for omicron (o) and vice versa, so that the word should be read as arotai, a noun, which he then translated as "farmer" and explains his choice grammatically as a substantive without its own article in apposition to the main noun "people," a practice documented elsewhere. His proposal convinced Casson.8

Yet in spite of Giangrande's demonstration, the emendation and translation as "farmer" is not as secure as it seems, based as it is on an etymological connection to ploughing, for all other known occurrences of arotai in vulgar Greek refer to laborers in general and, where specific, to dockworkers, not to farmers. Hence Giangrande's translation remains unsupported. Ironically, Huntingford, using the etymological link and translating the word as "ploughsmen," rejected the emendation on the grounds that until recently the plough remained unknown on the East African coast. ${ }^{9}$

\section{III}

But why should there be an emendation at all? In recent times editors consistently give the benefit of the doubt to original texts even in the face of corrupt appearances, because the seeming corruption might well be due to latter-day unfamiliarity with what once was common usage. Extreme prudence is now the rule, especially in cases where future additions to the corpus of a language can be expected. This applies to the vulgar Greek used in Egypt at this time because newly-studied papyri regularly add new words to that corpus. It is ironic that Giangrande began his article by citing four cases where emendations of the text of the Periplus were uncalled for, the text being 
correct as it was and then reaches the same conclusion in three of the four other cases he discusses after that, oratoi being the only exception!

Given this general stance, why reject the obvious meaning "visible" as incongruous? Is it really so? For instance-and these are but tenuous suggestions-could the text not mean "The visibly very big bodied people..." (oratoi as adverb) and thus not really add anything to the information given in the sentence. Or how about: "The persons one sees, very big bodied people "(oratoi as noun in apposition), implying that there were also people the traders did not see, perhaps in the interior. In any case why not stay on firm ground, leave oratoi as is and wait in the hope that future papyri will throw more light on its meaning? While editors naturally hate to concede defeat, such a moratorium would be a boon to users: in this case historians of Africa.

\section{IV}

The Periplus is too important a text to be ignored by historians of Africa, yet most of them feel unqualified to dispute the emendations of its editors and tend either to take their cue from better-placed colleagues or to accept the latest text edition as authoritative and limit themselves to discussing the implications of the text. Nevertheless, they do have their own ideas about what is possible and what not. Thus, for instance, Müller's and Frisk's "pirates" did not go down well after about 1960 with scholars who were wary of attributing disreputable stereotypes to Africans. This stance, rather than a critical attitude towards the emendation itself, might well explain why most of the relevant historiography has resolutely ignored these pirates. Basil Davidson already did this in his Old Africa Rediscovered.$^{10}$

No doubt a happy outcome, but nevertheless not a commendable one, because it resulted from a summary dismissal of embarrassing evidence. Some historians, however, were far more conscientious. One of the two editors of the first volume of the Oxford History of East Africa was Gervase Mathew, a classicist. He accepted the edition by Frisk as authoritative and so he mentioned pirates. He should, however, have drawn the attention of his readers to the fact that this was an emendation, but omitted to do so. For his part, Freeman-Grenville translated this portion of the Periplus from the Greek text in Frisk as a document in his published collection of documents-pirates and all-but also neglected to mention that it was an emendation. As a result, and presumably on the strength of Mathew's authority, the textbook by Robert Rotberg, which quoted the entire passage about the people of Rhapta, also accepted the emendation, now rendered as "piratical habits," a slightly less inflammatory expression that later found its way in the Cambridge History of Africa. ${ }^{11}$

As soon as the Casson edition became available, the disreputable pirates re-emended into respected farmers drew the attention of East Africanists, for this happened to be published just at a time when the chronology for the onset of agriculture in East Africa was being debated. In a review of Casson's book 
Mark Horton heartily approved of the new emendation, which fitted very well with his own views. ${ }^{12}$ Indeed, so timely are these farmers that by 1996 -and now without any more mention of emendation-they become a matter of course for Yajima, despite of the skeptical note justly sounded by Sutton: "...as could be deduced by preferring a particular wording..."13 One foresees that most historians will react like Yajima and that the "farmers" will in their turn haunt the historiography for a long time to come.

\section{$\mathbf{V}$}

Yet there should be further questioning. This case obviously raises the issue of how much interpretative weight such slender evidence can credibly bear and suggests the answer: actively search for further evidence to overcome such a situation. The scholars who are prepared to accept the latest emendation as definitive proof for the existence of a farming society by the middle of the first century $\mathrm{AD}$ rather than say one of hunter-gatherers or pastoralists, with all the implied social differences are clearly wrong. The evidence is too slender for such a momentous conclusion and one must search for more.

Further probing can begin by looking elsewhere in the selfsame Periplus. Giangrande justly remarks that whenever the communities met by GrecoRoman traders were not farmers but nomadic pastoralists, fishermen, or gatherers the author makes a point of mentioning this..$^{14}$ East Africa is not on that list. Furthermore, speaking about exports to the coast of the horn and of East Africa the Periplus (17:3) mentions: "Also, to certain places, wine and grain in considerable quantity, not for trade but as an expenditure for the good will of the Barbaroi." Contrast this with a passage about exports to the coast of South India (56: 21) : "...grain in sufficient amount for those involved with shipping, because the [local] merchants do not use it."15 Grain was not imported into East Africa in order to feed the Arab residents there, hence some acceptable cereals were available locally, and hence there was farming in the area, even though-like wine-cereals imported from Egypt were not grown locally and so were considered to be an exotic local delicacy.

Taken together, all these passages support a credible argument of silence. Farming was not mentioned because it was an expected situation. Only the exceptional needed to be mentioned-in this case, when people did not farm. Although arguments of silence tend to be weak evidence-and this one is no exception-still, in my view, this is much stronger evidence than the proposed emendation of oratoi can ever be, simply because it rests on an untampered text. So one can maintain that it is more likely than not that local people farmed in the middle of the first century $\mathrm{AD}$. But the matter need not rest there. More can still be gained, especially from archeological research. Indeed, it is not impossible that one day direct proof may be found on the Tanzanian coast in the shape of plant remains or pollen from the first century. At that point the slender bit of negative evidence would become a mere footnote to incontrovertible direct evidence and the paradox between slender 
data and huge consequences would vanish. Meanwhile we must be content with "more likely than not."

\section{Notes}

1. I doubt whether this note would ever have been written without the input of Professor Ken Sacks, a specialist in Greek history to whom I ran for help in the assessment of oratoi and The arotai proposed emendation. Thanks, Ken!

2. Lionel Casson, ed., The Periplus Maris Erythraei: Text with Introduction, Translation, and Commentary (Princeton, 1989), 6n7, for a reference to the much debated date. The attempts by Gervase Mathew to claim that the manuscript in the British Museum is partly independent from that at Heidelberg and that the original manuscript is a "cumulative text," and his proposed dates are all unconvincing. Cf. Mathew, "The Dating and the Significance of the Periplus of the Erythraean Sea" in H. Neville Chittick, and Robert I. Rotberg, eds., East Africa and the Orient: Cultural Syntheses in Precolonial Times, (New York,1975), 147-63. Mark Horton, "The Periplus and East Africa," Azania 25 (1990), 95, narrows the dates from AD 4070 to before $\mathrm{AD}$ 40-55.

3. Casson, Periplus, 6 (Greek text), 7 (his translation).

4. Hjalmar Frisk, "Le Périple de la Mer Érythrée suivi d'une étude de la tradition et la langue," Göteborgs Högskolas Arsskrift, 33 (1927), 6; G.W.B. Huntingford, trans. and ed., The Periplus of the Erythraean Sea (London, 1980), 30, 63.

5. Casson, Periplus, 82,83.

6. Looking at oratoi without knowledge of Giangrande's article, Ken Sacks proposed the same interpretation.

7. G. Giangrande, "On the Text of the Periplus Maris Erythraei," Mnemosyne 28 (1975), 293-94.

8. Casson, Periplus, 253-54 . Technically the emendation is quite attractive because of the similarity between alpha and omicron. Omicron was written as a perfect circle and alpha as a loop in the shape of a circle, the only visual difference being alpha's two tiny extrusions at the beginning and the end of the loop.

9. On the etymology see Huntingford, Periplus, 63. The meanings "laborer" or "dockworker" in vulgar Greek were established by Ken Sacks from a perusal of the Perseus database.

10. (London 1959), 151, where he discusses the contents of the Periplus. The same distaste for pirates, rather than a critical attitude toward the emendation, probably explains their absence in A.M.H. Sheriff's "The East African Coast and its Role in Maritime Trade" in Unesco General History of Africa II (Berkeley, 1981), 555.

11. Roland Oliver and Gervase Mathew, eds., History of East Africa I (Oxford 1963), 95; G.S.P. Freeman-Grenville, The East African Coast (Oxford 19620, 2; Robert I. Rotberg, A Political History of Tropical Africa (New York,1965): 28- and 27n59 for the link with Mathew; J.D. Fage, ed., The Cambridge History of East Africa 2 (Cambridge, 1978), 373 (by Roland Oliver and Brian Fagan).

12. Horton, "Periplus," 96.

13. J.E.G. Sutton "East Africa: Interior and Coast," Azania 29/30 (1994/95), 231; H. Yajima, "Some Problems on the Formation of the Swahili World" in Shun Sato and Eisei Kurimoto, eds., Essays on Northeast African Studies (Osaka, 1996), 348n2.

14. Giangrande, "Text," 294. See also Periplus 20:16; 27:20; 30:6-7; 33:16.

15. Casson, Periplus, $60 / 61$ and $84 / 85$. 